Online networks of civil society actors as an indicator for politicization? A hyperlink analysis on the food safety issue in Germany

by P. Miltner, D. Maier, B. Pfetsch, A. Waldherr

To cite this article:

Miltner, P., D. Maier, B. Pfetsch \& A. Waldherr. (2013). Online Networks of Civil Society Actors as an Indiocator for Politicization? A Hyperlink Analysis on the Food Safety Issue in Germany. Catalan Journal of Communication \& Cultural Studies, 5(2), 201-220.

Published in:

Catalan Journal of Communication \& Cultural Studies (Link to article)

Copyright:

The Authors, 2013

DOI:

10.1386/cjcs.5.2.201_1 


\title{
Online networks of civil society actors as an indicator for politicization? A hyperlink analysis on the food safety issue in Germany
}

\author{
Authors: \\ Peter Miltner, Daniel Maier, Barbara Pfetsch, Annie Waldherr \\ (Freie Universität Berlin, Germany)
}

\begin{abstract}
This article focuses on the constellations of actors engaged in the food safety debate in Germany and the potential of civil society organizations for mobilization and politicization of the issue. In an exploratory case study we assess the structure of communication between these organizations by applying hyperlink analysis. Our study sheds light on the nature of the issue network and in particular on their linkages with media and political actors. We interpret the patterns of the communication network with respect to civil society actors' chances to make the issue of food safety salient on the agenda, to mobilize around it and to politicize it. In fact, our empirical study shows that the structure of linkages between civil society actors, media organizations and political actors in Germany creates a favourable opportunity structure for making the food safety issue salient and politicize it in the offline world.
\end{abstract}

\section{Keywords:}

Food safety, issue network, civil society actors, politicization, mobilization, hyperlink analysis 


\section{Introduction $^{1}$}

Chemicals and poisons in animal feed, dioxin in eggs or the sale of rotten meat: food safety scandals like these have shocked German consumers in recent years and contributed to the fact that food safety has become an emotional issue of general interest and a recurrent issue with high news value (Anderson 2000). At the same time even the observation and attention of the media does not seem to cure the lack of public understanding of food production or provoke stricter control (Blue 2010). Instead, one can observe a gap between producers and consumers which feeds into 'an emergent politicized discourse about the risks associated with food and eating' (Blue 2010: 150). In the increasingly politicized and publicly observed policy arena, a shift in the constellation of actors who have an influence on food policy can be observed. What used to be an exclusive domain of government agencies has become a sphere of influence for especially two other groups - the food industry and civil society actors. Now, these actors together define 'the public interest in food policy' (Lang et al. 2009: 12).

The public discourse on food safety is of a high importance for the actors in the policy field since 'the power to set the public agenda, to frame the debate and to silence opponents become a key resource' (Lien 2004: 10) for influencing the political agenda too. In this situation, the role of the mass media and their power to set the public agenda have become essential for the success of politicizing the issue (Baumgartner and Jones 1991). However, as Wolfsfeld (2011: 16) points out, the media's selection bias produces a 'cumulative inequality' of voices and publicly heard interests: Those actors who depend most strongly on the media have the most difficult barriers to its access. Compared to political actors who 'enjoy privileged access [...] through their social and political power position and their economic and cultural resources' (Maeseele 2011: 87), civil society actors have to struggle to gain voice in the media. 
If we carry this argument further and adopt it to the debate about food safety, we can assume that the chances of civil society actors to publicly mobilize for a policy change in the food sector in the traditional media are not too high. However, they might increase their prospects of success under three conditions: First, if they manage to form communication networks across a broad range of civil society actors and build issue or advocacy coalitions (Jenkins-Smith and Sabatier 1994, Sabatier 1988, Sabatier and Weible 2007), civil society organizations might be strong enough to make an issue salient and to mobilize the public on common interpretations of the problem. Second, we assume that in the light of the selection bias of traditional mass media, the opportunities of the Internet are critical for starting advocacy coalitions and issue networks by civil society actors. Third, if the issue network reaches out beyond the civil society sector and appeals to other important stakeholders, the chances of drawing attention to a common interpretation of the issue might be increasing. Thus, we can assume that if all three conditions are fulfilled, there will be a 'discursive opportunity structure' (Koopmans and Statham 1999: 228) that renders 'access to the news media and to political resources' (Koopmans 2004: 32) and eventually promotes the politicization of food safety policies.

Our study takes up this framework and aims to reveal the discursive opportunity structure for mobilization and the politicization of food safety by civil society actors in Germany. We ask: what do the online communication networks of civil society actors on the food safety issue look like, what is the constellation of the actors and to what degree are they connected with powerful stakeholders such as established political actors and traditional news media? We assume that civil society actors use the potentials and the advantages of the Internet for their public communication strategies. In doing so, they may bypass the news selection bias of the traditional media (Koopmans and Zimmermann 2010) and at the same time profit from the advantages of an emerging 'hybrid news system' (Chadwick 2011), in which old and new media become more and 
more interconnected. Therefore we focus on communication networks on the Internet and pay particular attention to the linkages with traditional media and political actors. We assume that the denser the network of civil society actors and the stronger the links between them are, the higher the chances for the mobilization and politicization of the issue in public debate and political decision making. Our empirical analysis draws on Internet crawls starting from the websites of selected civil society actors which allows us to identify the online linkages and on this basis draw conclusions about the potential of the issue to become salient in public and politics.

This article is organized as follows: In the first section, we describe the general constellation of food safety policy in Germany and lay out our argument why civil society actors might gain voice if they use their online communication to set up a viable discourse coalition. Second, we explain our methodological approach to identify and to analyse online issue networks in the food safety sector. The third section is devoted to the findings of our exploratory empirical network analysis. From the communication network of civil society actors on food safety in Germany we draw conclusions about the potential of politicization of the food safety issue in Germany.

\section{Food safety policy - the German case}

For the longest time in the 20th century, food safety and consumer protection has not been an independent issue field in German policy making (Barlösius 2011, Janning 2011). Nutrition and food policy were integrated in the domain of agricultural policy, which was dominated by 'iron triangles' consisting of special interest groups, ministerial bureaucracy and parliament (Barlösius 2011). With the appearance of scandals and food crises in the 1980s and 90s, especially the outbreak of bovine spongiform encephalopathy (BSE) in cattle, also known as 'mad cow disease', a shift towards nutrition and food policy as independent policy issues could be 
observed. These also included food safety as an important aspect (Barlösius 2011). The coalition government of Social Democrats and the Green party announced the 'agricultural turnaround' ('Agrarwende' in German) in the early 2000s, which aimed at integrating ecological aspects and concerns related to health into agricultural policy (Paul 2007). At the same time, there were major rearrangements in the political sector with the reconfiguration of the Federal Ministry for Nutrition, Agriculture and Forestry into the Federal Ministry for Consumer Protection, Nutrition and Agriculture. ${ }^{2}$ What is more, two new bodies, the Federal Office of Consumer Protection and Food Safety (BVL) as well as the Federal Institute for Risk Assessment (BfR) were founded (Paul 2009). ${ }^{3}$ While new actors entered the policy arena and influenced the newly constituted policy field of food safety (Feindt and Kleinschmit 2011), the traditional political actors remained still dominant in decision making (Janning 2011). Thus, in order to influence the political agenda in the field of food safety the connections to political actors are still of central importance.

When it comes to the public discourse on food safety, Paul (2007) observes that the reconfiguration of the policy field allowed the re-activation of discourses and an empowerment of certain groups such as NGOs that had been marginalized before. She discovered that the German policy discourse on agriculture has broadened through the inclusion of food safety concerns and consumer rights, and that notions such as 'consumer protection' and 'environmental sustainability' gained more prominence and importance (Paul 2009). Moreover, media attention focused on safety issues in times of food scandals such as BSE or Dioxin in animal feed (De Jonge et al. 2010, Feindt and Kleinschmit 2011). In some of these cases, like in the BSE scandal, civil society actors did not play a strong role in the media coverage compared to established political actors (Feindt and Kleinschmit 2011). In other cases, however, civil society actors managed at least temporarily to gain media attention. A study analysing the coverage of agricultural biotechnology in Belgium shows that a campaign of a coalition of NGOs was very 
successful in drawing media attention (Maeseele 2011: 97-98). Also German NGOs were provoking large media attention with actions against GMOs (Rucht et al. 2008). The studies demonstrate that in times of large media interest for food issues civil society actors manage to establish a discursive opportunity structure for public debate and politicization. However, it also seems that a necessary precondition for this would be that civil society actors team up in order to form effective communication networks and political coalitions.

\section{Civil society actors and their online networks}

In our study on the online networks of civil society actors in the food safety sector, we draw on different trajectories of social and communication research and include three bodies of literature: First, we look at civil society actors as challengers in public debate from a social movement studies' point of view. Second we discuss theories of network public sphere from a communication sociology angle and thirdly we relate to studies on the meaning of hyperlink analysis and their application to the analysis of issue networks.

Our focus on civil society such as non-governmental organizations (NGOs) or social movement actors is rooted in the idea that these actors 'articulate political interests and confront the state with demands arising from the life worlds of various groups' (Habermas 2006: 417). However, Habermas (2006) argues that compared to actors from politics or lobbyists from economically motivated special interest groups who dispose of high material resources, it is much more difficult for civil society actors to have access to the media and the public sphere and thus public influence. Provided that the issue of food safety is of essential importance to consumers we assume that public interest groups, NGOs and civil society actors are most likely to represent these interests and thereby 'challenge' the existing power relations between governmental offices 
and the industry. In research on social movement organizations, the notion of 'challengers' has been introduced by Tilly (1987) and Kriesi et al. (1992: 220) who use the term to denote the differentiation of actors in political systems between 'authorities' or 'members of the system' and outsiders who challenge their decisions. Kriesi (2004: 196) specified the definition of challengers as 'actors who do not have routine access to the decision-making arena or to the established media'. Challengers may apply different strategies of drawing attention to their causes, also depending on the level of media attention for an issue. For instance, a peak in coverage might create windows of opportunities and thus enable challengers to be heard in the media (Kriesi 2004). Media access, as mentioned earlier, is an important dimension of the discursive opportunity structure (Koopmans 2004) for the politicization of an issue. We assume that such an opportunity structure emerges if challengers manage to build up strategic ties to influential stakeholders and actors in the media, because such linkages increase the salience and the chances for the politicization of the issue, once the conditions are favourable. This is also in line with the considerations of Habermas (2006) who stresses the meaning of associational networks of different actors for the creation of political issues.

Second, the Internet has become an important avenue for such associational networks and also for the process of issue and agenda building, which rely on linking and networking as basic principles (Chadwick 2006). The basic idea of the 'network society' (Castells 2010) has also informed communication research. Raupp (2011) for example proposed the model of a 'networked public sphere' thereby stressing the perspective of organizational communication to the Internet. Most relevant for our study is the idea that in this networked public sphere horizontal communicative ties between organizational actors on the meso-level emerge that are open towards vertical communicative ties to the levels of individuals on the one hand and to society at the other hand. 
This logic of the Internet is reflected in network communication, which according to Bucher et al. (2008) may be analysed on four different levels: a technical, a morphological, a hypertextual and an interactional-social level. The morphological and the hypertextual level focus on the function of hyperlinks which constitute the ties of different actors and which connect actors on the level of documents. The approach of examining linking patterns between different actors and their websites can, of course, only be a proxy for their connections and alliances in the 'real world'. However, there has been research showing that offline affiliations (such as common issues, financial or membership ties) between NGOs are also visible in their hyperlinks to each other; there was more linking between those NGOs which also had offline connections (Pilny and Shumate 2012). What is more, there is a large body of literature on networks constituted by hyperlinks, seeing them for instance as 'ties of affinity, paths of communication, tokens of mutual aid in achieving public recognition, and/or potential avenues of coordination' (Burris et al. 2000: 215, for further discussions on the meaning of hyperlinks see e.g.; Ackland and O'Neil 2011, Gonzalez-Bailon 2009, Kim 2012, Pilny and Shumate 2012). As a consequence, hyperlink network analysis was proposed as a method for studying social structures on the Internet (Park 2003). Furthermore, also the research on social movements has drawn on the analysis of linking patterns between social movement organizations on the Internet (Diani 2000), which has even lead to the conceptualization of 'online social movements' (Ackland and O'Neil 2011: 177).

The research on hyperlinks has also been used to study networks dealing with a certain issue. The term 'issue network' has been introduced (Marres 2005, Rogers 2002) to denote 'web pages that are connected by hyperlinks and that all treat a particular issue' (Marres 2005: 97). These issue networks, although merely held together by weak ties (= hyperlinks), 'facilitate the articulation of issues as public affairs' (Marres 2005: 95). 
The approach of hyperlink network analysis is particularly promising for our study, because it allows examining on the one hand the structure of a communication network and on the other hand the thematically centred communication that focuses on a particular cause. We apply these ideas to the issue of food safety and take account of the differentiation of actors in this policy field and the ever growing meaning of online communication in nutrition and food safety policy. We know that online communication for the consumer plays an important role as a source of information on food safety (Whatley et al. 2005). We can also observe that the Internet has become a communication channel for food producers to influence public opinion and consumers with their PR instruments thereby aiming at depoliticizing the discourse on food (Kleinschmit 2010).

However, our study focuses on the question to what degree the Internet has offered an avenue for NGOs and citizens to create a critical public. While studies demonstrate that the Internet and for instance YouTube videos are used by a wide range of actors such as advocacy groups as means to conduct campaigns and to disseminate educational messages (Rhoades and Ellis 2010), we hardly know about the structure of communication of this critical counter public. Therefore our empirical study aims at revealing the online issue networks on food safety by civil society actors and drawing conclusions about its potential for mobilization and politicization of the issue.

\section{Methodology of the study}

In this section we explain the methodological approach of the study that enables us to analyse the constellation of actors in the food safety issue network. As a first step, we identified a number of civil society actors of high centrality and importance in the food safety sector that mark the starting points for the network analysis. Starting from the websites of these actors, we crawled the 
Internet and identified other actors they were linked to. As a second step, we reconstructed the food safety issue network for our analysis by checking the identified pages for specific food safety key words and eliminating those websites that were not relevant for the issue.

\section{Identification of starting URLs}

In order to identify the linking patterns existing between challenger actors on the Internet, we first had to identify actors and their websites, so called 'seed URLs' (govcom.org 2012). We therefore conducted searches on the German version of Google (www.google.de), which is the most used search engine amongst German Internet users (Webhits 2012). Since Google tends to favour institutional actors to the disadvantage of civil society actors (Gerhards and Schäfer 2010), we included results up to the twentieth results page. In practice, we searched Google in May 2012 for ten different German search terms such as 'food safety' or 'food scandal', and at the same time restricted the search to results from Germany. ${ }^{4}$ We also consulted literature and food experts in order not to miss any actor of importance. ${ }^{5}$ Eventually, we identified a list of 52 possible actors and their domains and checked 1) if the website was available, 2) whether food safety was an important topic on the website and 3) whether the section on the website concerning food safety was up-to-date. After this identification process we finally selected eight German-based seed URLs (shown in table 1) for the crawling process which took place in the beginning of June 2012. These challenger actors and their websites are now briefly introduced. ${ }^{6}$

Table 1: Overview of seed organizations.

\begin{tabular}{|l|l|l|}
\hline Name of organization (URL) & Type of organization & Type of website \\
\hline Foodwatch (http://www.foodwatch.de) & NGO & website \\
\hline $\begin{array}{l}\text { Greenpeace Germany } \\
\text { (http://www.greenpeace.de/themen/landwirtschaft) }\end{array}$ & $\begin{array}{l}\text { German section of } \\
\text { international NGO }\end{array}$ & website \\
\hline $\begin{array}{l}\text { Slow Food Germany } \\
\text { (http://www.slowfood.de) }\end{array}$ & $\begin{array}{l}\text { German section of } \\
\text { internationally } \\
\text { existing NGO }\end{array}$ & website \\
\hline $\begin{array}{l}\text { Campaign "Meine Landwirtschaft - unsere Wahl" } \\
\text { (http://www.meine-landwirtschaft.de) }\end{array}$ & $\begin{array}{l}\text { campaign of different } \\
\text { NGOs and initiatives }\end{array}$ & campaign website \\
\hline Verbraucher-Papst & individual actor & blog \\
\hline
\end{tabular}




\begin{tabular}{|l|l|l|}
\hline (http://www.verbraucher-papst.de/category/essen-und-trinken) & & \\
\hline $\begin{array}{l}\text { aid Infodienst } \\
\text { (http://www.aid.de/verbraucher/lebensmittelsicherheit.php) }\end{array}$ & consumer association & website \\
\hline $\begin{array}{l}\text { Verbraucherzentrale Bundesverband (VZBV) } \\
\text { (http://www.vzbv.de/Ern\%C3\%A4hrung.htm) }\end{array}$ & $\begin{array}{l}\text { consumer association, } \\
\text { individuals and } \\
\text { organizations as } \\
\text { members }\end{array}$ & website \\
\hline $\begin{array}{l}\text { Verbraucher Initiative (VI) } \\
\text { (http://www.verbraucher.org/verbraucher.php/cat/3/title/Ern\%E4hru } \\
\text { ng) }\end{array}$ & $\begin{array}{l}\text { umbrella organization } \\
\text { of consumer } \\
\text { associations }\end{array}$ & website \\
\hline
\end{tabular}

Foodwatch is a 'prominent private food and consumer watchdog' (Paul 2009: 177). It was founded in 2002 and aims at disclosing scandals in agriculture and food production (Janning 2011: 172). In short, 'foodwatch fights for the right of consumers to honestly know what they are buying and to enjoy good food that is healthy and uncontaminated' (foodwatch 2012). Actors like foodwatch articulate problems in the food sector as risks, and base their argumentation on scientific knowledge (Barlösius 2011: 272), as also does the German section of Greenpeace, when they for instance fight against GMOs or pesticides in food (Greenpeace 2012). Other actors from German civil society which are active in the sector of food and agriculture politics are the Campaign "Meine Landwirtschaft - unsere Wahl” ("My agriculture - our choice" in English) and the German section of Slow Food. The former inter alia fights for a right to healthy food, against excessive use of fertilizers and pesticides as well as against GMOs (Meine Landwirtschaft 2012a) and 'is supported by 40 organizations and initiatives in many areas of society dealing with agriculture, nutrition, environment, nature protection, animal welfare, consumer protection, health, regional and international development' (Meine Landwirtschaft 2012b). Slow Food Germany is one of the supporting organizations of the campaign. Apart from engaging in the campaign, Slow Food fights for regionally produced, healthy quality food and a 'culinary culture', but also against the use of GMOs (Slow Food 2002). Another actor we chose as a starting point is the private blog Verbraucher-Papst (a literal translation of the blog name into 
English would be "consumers' pope"), which publishes news on consumer issues and inter alia has a section on food.

In addition to these five actors we also included the three consumer associations aid Infodienst (aid info-service consumer food, agriculture, protection), Verbraucherzentrale Bundesverband, ( $V Z B V$, The Federation of German Consumer Organizations) and Verbraucher Initiative (VI) into our list of seed URLs. Aid Infodienst 'has been active for more than 60 years in the fields of agriculture, consumer protection nutrition, and environment' (aid Infodienst 2012) and maintains several websites on food and also food safety issues. VZBV and VI are the two most important consumer organizations in Germany according to Janning (2011). They do follow strategies that are different from each other and set different priorities as VZBV is an umbrella organization which represents several other consumer associations while VI is mainly a membership organization which was initially a movement actor. Somehow, these associations already dispose of connections to political actors as they represent consumers' interests in parliament hearings or the like. What is more, VZBV receives public funding, describes itself however as 'politically independent' (VZBV 2012).

Even if some of these actors do not exclusively focus on food safety or have a focus on only one special part of the issue, we assume that if a food safety issue occurs, these actors will actively bring up further information on their websites informing about food and food safety issues.

\section{Crawling the Web}

In the next step we used the web crawling tool 'Issue Crawler' to search the Internet. ${ }^{7}$ It functions by automatically identifying and fetching all hyperlinks starting from a certain number of seed URLs. There are different ways of using the Issue Crawler (govcom.org 2012); for our purposes we decided to perform a snowball analysis since it is the least restrictive way of crawling. By 
operating this kind of mechanism, very generally speaking, the crawler includes all websites into the network, which have been linked to by any of the starting points. In this procedure, one hyperlink is sufficient to include another website into the network.

More specifically, there are the following crawler settings, which describe its exact functioning, namely crawl depth and degree of separation (see also figure 1). Crawl depth designates the vertical dimension of crawling, i.e. the fact that links within a website are fetched and included into the analysis up to a certain degree. We chose a depth of two, meaning that the crawler captures the links on the starting page and moves on to those pages within the website which are pointed at by the starting page. This procedure is repeated once more: so all pages pointed at by the ones from level 1 are finally included, reaching the depth of two.

Figure 1: Crawling logic underlying the network identification.

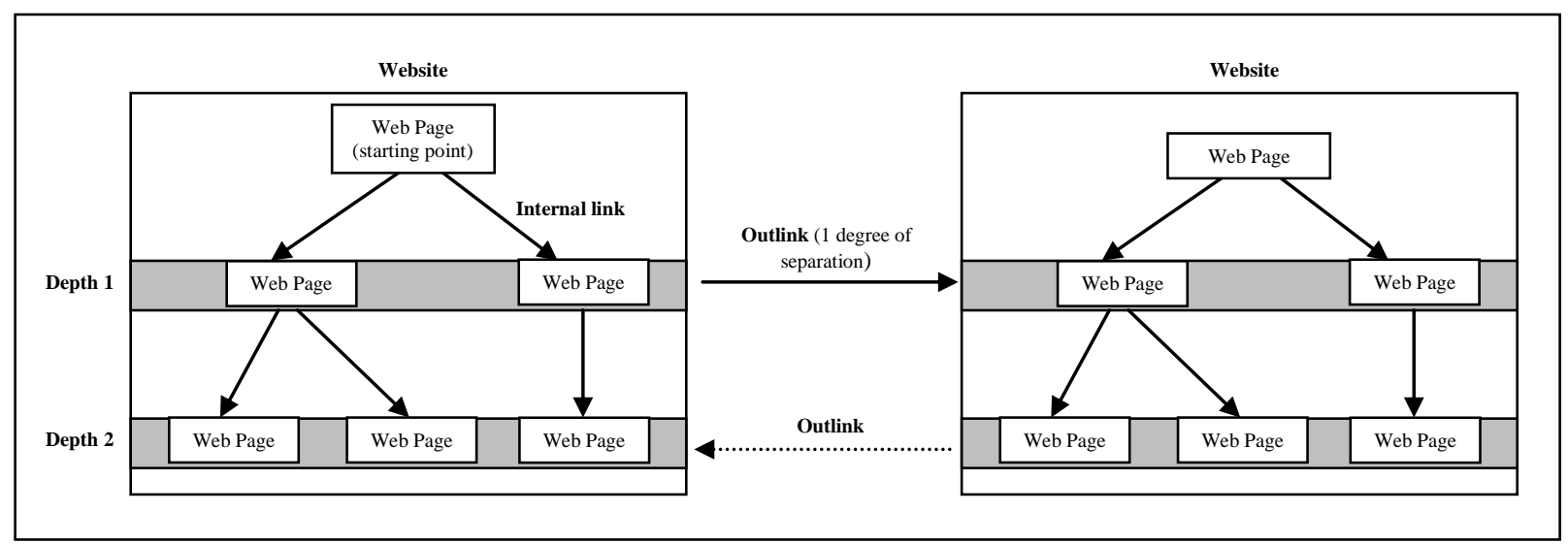

The degree of separation in contrast indicates the horizontal dimension of crawling. Here, all of the outlinks, i.e. hyperlinks which point to external websites or pages within these websites, are followed. We chose a degree of separation of 1, meaning that the first horizontal level of outlinks is fetched and included into the network. ${ }^{8}$ Finally, the websites identified by the outlinks of the starting pages are also vertically crawled and all outlinks from these sites linking back to the 
already existing population of sites are also contained in the network. Practically, this means that all websites which receive a link from the starting websites remain in the network and that all of their hyperlink connections back to the starting sites or to other sites linked to by the starting sites are mapped in the final network.

\section{Identifying issue networks}

The Issue Crawler merely identifies and follows hyperlinks and adds sites to the networks regardless of their content. Since we aim at mapping thematic networks that deal with the issue of food safety, we used another tool to search the pages in our networks for specific search terms. For this purpose we used the Visual Web Spider tool which automatically scrapes, i.e. searches web pages for certain keywords. ${ }^{9}$ As we work with a broad definition of food safety, we consider all kinds of (potential) health problems connected to food as food safety problems. This may include food contamination or the occurrence of food scandals connected to food safety, problems associated with certain substances in food such as genetically modified substances or nano particles as well as problems caused by the consumption of (too many) unhealthy ingredients, resulting in public health problems such as obesity and diseases connected to it. We therefore used a broad list of search terms in order to track the different facets of our issue; we oriented ourselves towards the approach of De Jonge et al. (2010) and elaborated the search terms shown in table 2.

Table 2: List of search terms.

\begin{tabular}{|l|l|l|}
\hline $\begin{array}{l}\text { A: denomination } \\
\text { of Issue* }\end{array}$ & $\begin{array}{l}\text { B: Terms for } \\
\text { food }\end{array}$ & $\begin{array}{l}\text { C: Terms related to food safety problems and food } \\
\text { regulation bodies }\end{array}$ \\
\hline Food safety & $\begin{array}{l}\text { Food / aliment / } \\
\text { feed }\end{array}$ & $\begin{array}{l}\text { Germ / Epidemic / scare / Illness / health / Infected / borne / } \\
\text { Contagious / Contaminated / polluted / GM food / Genetical / } \\
\text { hazard / bioengineer / harmful / scandal / hygien / Risk / EFSA / } \\
\text { FDA / FSA }\end{array}$ \\
\hline $\begin{array}{l}\text { Lebensmittel- } \\
\text { sicherheit }\end{array}$ & $\begin{array}{l}\text { Lebensmittel / } \\
\text { Nahrung / } \\
\text { Futter }\end{array}$ & $\begin{array}{l}\text { Erreger / Keim / Epidemie / Seuche / Krankheit / Gesundheits / } \\
\text { Infiziert / Verunreinig / Kontamin / Belast / Gentechni / gefähr / } \\
\text { Gefahr / Skandal / Hygien / Risiko / EFSA / BVL / BAG }\end{array}$ \\
\hline
\end{tabular}


*The search is both performed in English and German, since both are languages of the overall research project; some terms are cut after a certain point as to ensure different words are tracked, e.g. by searching for "genetical", this may include the words "genetical" or "genetically"; the search is performed in the following manner: relevant are pages that contain term of column 1 or a combination of terms in columns 2/3; this makes A OR ((B) AND (C)).

The different columns in the table were combined by the search operators OR and AND. More precisely, for a page to be relevant for the issue, it has to contain either the word food safety (first column) or a combination of one term in column 2 and one term in column 3. This approach certainly does not ensure that all pages and sites remaining in the network ultimately deal with our issue, but it does ensure that one of our search terms or a combination of them are mentioned on the pages; it also significantly reduces the amount of data (from 14.389 pages in the original network to 2.806 in the final, scraped one) and thus ensures the data can be dealt with more easily.

The networks are analysed on the level of organizations. In order to obtain this level of aggregation, all of the 2.806 pages in the network were first attributed to a total of 258 different domains. In a second step, these domains were checked for the actor or organization publishing them. ${ }^{10}$ If an actor or an organization published different domains (which was e.g. the case for foodwatch, whose domains foodwatch.de and abgespeist.de were inter alia contained in the network), all of these different domains were attributed to the organization, thereby resulting in a total of 231 organizations or individual actors (such as bloggers) in the network (displayed in figure 3).

We classified all organizations and actors in the network into five broad categories, which we built following Habermas (2006), who subdivides the public sphere regarding its power structure into four subcategories (political, social, economic and media power) and Rucht et al. (2008), who make a similar subdivision into four categories. We added a fifth category (single 
citizens/bloggers), for those actors who could not be attributed to one of the other categories, taking into account the possibilities of articulation the Internet offers to individuals. Accordingly, we distinguish between these five categories (see also table 3): 1) political and state actors, 2) socioeconomic pressure groups, 3) non-profit actors of civil society, 4) media and journalists as well as 5) single citizens and private persons. ${ }^{11}$ By doing so, we can identify the interlinking patterns of different societal groups and the coalitions they may form.

Table 3: Type of actor - Coding categories for the actors associated to the domains.

\begin{tabular}{|l|l|}
\hline Category & Description \\
\hline Political and state actors & $\begin{array}{l}\text { All actors from politics and state, such as government, parliament, } \\
\text { political parties, state executive agencies, judiciary, police, international } \\
\text { organizations, etc. }\end{array}$ \\
\hline $\begin{array}{l}\text { Socioeconomic pressure } \\
\text { groups }\end{array}$ & $\begin{array}{l}\text { All actors from the business sector, such as firms and companies, } \\
\text { employer's organizations. Also trade and professional associations, } \\
\text { employee's associations and trade unions belong here. }\end{array}$ \\
\hline $\begin{array}{l}\text { Non-profit actors of civil } \\
\text { society }\end{array}$ & $\begin{array}{l}\text { All non-governmental actors, civil society groups and groups from the } \\
\text { movement sector such as environmental or food movements and groups, } \\
\text { welfare organizations or foundations, consumer organizations and } \\
\text { groups, scientific and research professionals or institutes, churches \& } \\
\text { religious organizations belong here. }\end{array}$ \\
\hline Media and journalists & $\begin{array}{l}\text { All actors from the media sector, such as online news platforms, online } \\
\text { outlets of traditional media and sites from publishing and film } \\
\text { companies belong here. }\end{array}$ \\
\hline Citizens and private persons & $\begin{array}{l}\text { All single actors with an online presence who do not belong to } \\
\text { categories 1-4, such as single or groups of bloggers belong here. }\end{array}$ \\
\hline Other actors & $\begin{array}{l}\text { Forums, content sharing platforms, campaigning platforms, etc.; also } \\
\text { sites which cannot exactly be identified belong into this category. }\end{array}$ \\
\hline
\end{tabular}

\section{Results}

The first finding on the communication networks in the food sector relates to the constellation of actors and the coalitions of challengers. Here we find that NGOs and civil society actors indeed are best linked among themselves. Taken together with the citizen actors, these two groups constitute the challengers and account for almost $44 \%$ of actors in the network. The second most important group in the network are media actors with about $34 \%$. Political actors seem to be of 
minor importance in the network, since they only account for $12 \%$. Socioeconomic actors play the least important role with a share of 8 percent of actors in the network (see figure 2).

Figure 2: Share of organizations in the network, by type.

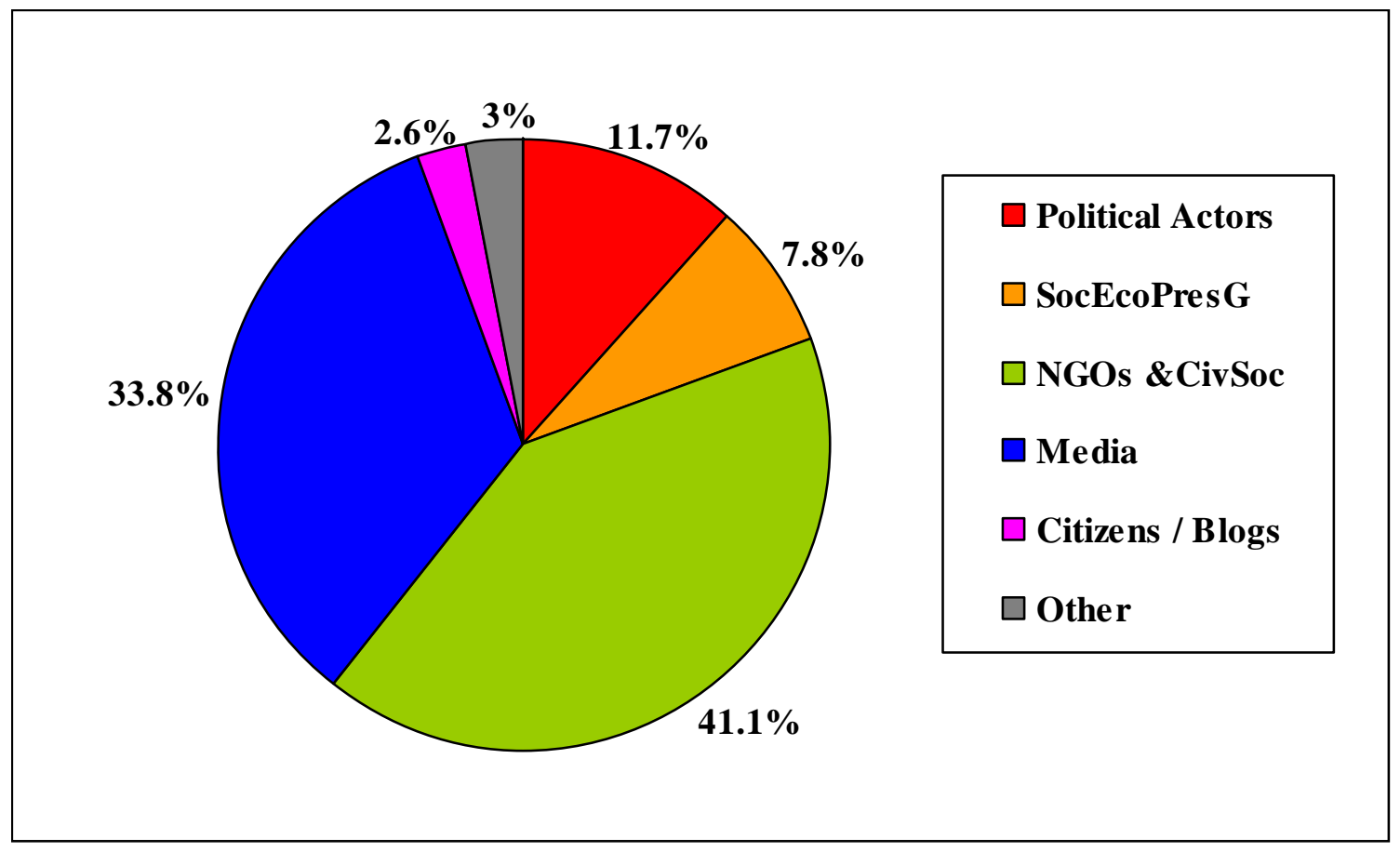

The distribution of actors and their centrality are displayed in the network graph in figure 3 . As measure of centrality for the actors in the network we chose the indegree, i.e. the number of inlinks an actor or organization obtains from other actors. This measure can be seen as a sign of importance or prestige that is attributed to them by the other actors (Wassermann and Faust 1992) and is shown by the size of the nodes in the image. Concretely, the more inlinks an actor receives from different other actors, the more central it is and thus the bigger gets its node. Hence, this approach avoids that two domains with a lot of mutual links would be identified as central actors although they do not have any further connections to other nodes of the network. 
Figure 3: German issue network on food safety.

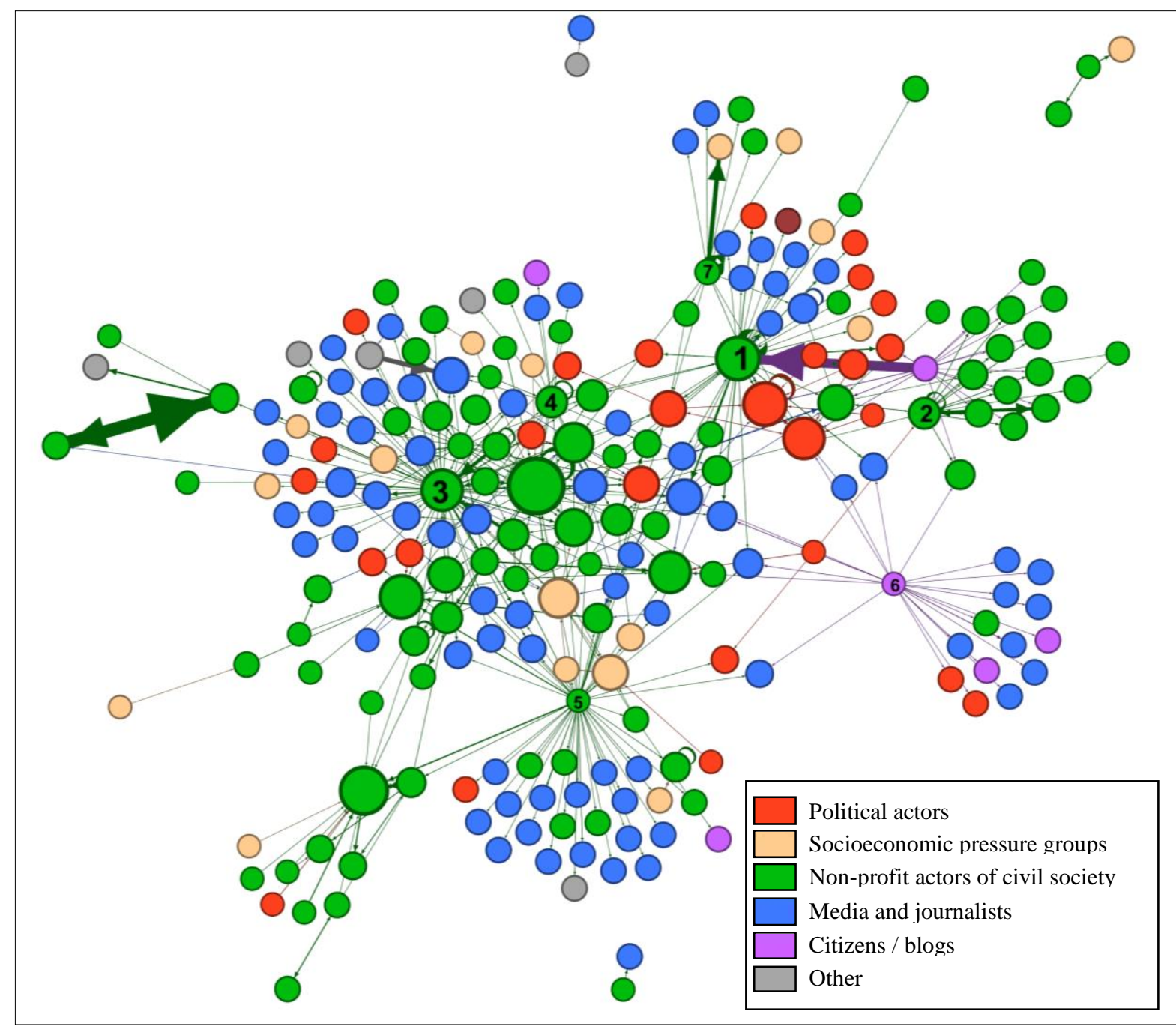

Size of nodes according to indegree; thickness of arrows according to number of hyperlinks between the nodes; seed organizations are marked with numbers in the graph: 1) foodwatch, 2) VZBV, 3) Campaign "Meine Landwirtschaft", 4) Greenpeace, 5) Slow Food, 6) Verbraucher-Papst, 7) VI.

In the graph, there is an arrow between two nodes if there was at least one hyperlink between two actors. Originally, we found 1.637 hyperlinks between the actors in our network, but in figure 3, the final number of 435 ties between different nodes is shown, with the thickness of ties reflecting the original number of hyperlinks between them.

Since some domains were merged to one single node in the figure in case they belong to the same actor or organization, in some cases, the nodes are linking to themselves in case there was a link between two of the domains before the merging process. Another pattern that may be found in the 
graph is groupings of several actors which are isolated from the central network. This can be explained by the scraping process: there used to be actors connecting the isolates to the network, but as the actors websites didn't contain a minimum combination of our search terms, they were removed from the network, thereby leaving the isolates.

When it now comes to the most central actors in the network, we can observe that the 25 most central actors in terms of indegree obtain a considerable amount of inlinks, namely 179 or about $41 \%$ of all ties in the network. From these 25 actors, 17 can be attributed to the group of civil society actors, 4 to the group of political actors, 3 to the group of media whereas only 1 socioeconomic pressure group can be found amongst them. On the one hand, the high importance of challenger actors in the network and amongst the most central actors speaks for the strength of the coalition of the challengers. On the other hand, the strong representation of civil society actors in the core of the network and the fact that they make up for the central nodes were not overly surprising, since we started the crawling process exclusively from this type of actor. Four organizations out of eight seed URLs (foodwatch, the campaign "My agriculture - our choice", Greenpeace and VZBV) were found in the list of the 25 most central organizations. At the same time, we also found that not all of the seed organizations were of relevance to the network, concretely the association aid Infodienst.

When assessing the constellation of actors in the network we found that the network is dominated by challenger actors and a considerable amount of actors stem from the media, representing both websites of traditional media or genuine online media. However, most of these actors do not hold very central positions in the network and a relevant share of them are clustered around single other actors in the network, who might have special collections of links referring to media coverage on the food safety issue. The contrary pattern may be observed for the political actors in the network: their total share in the network is less important, but the most relevant actors in the 
policy field (namely BMELV, BfR and BVL) can all be found amongst the most central actors. Thus, we found that a few important established political actors take a central position in the core of the network while a great deal of media is represented at the network periphery or in rather less central positions.

A complete description of the communication and the coalition structure in the food safety network must also include all the linking patterns that exist between the different actor groups. Table 4 sheds a clearer light on these connections as the percentages shown in the rows represent the share of all links referring to the senders of links, and the numbers in columns refer to the share of all links that can be attributed to the receivers of links. The findings demonstrate that challenger actors account for $85 \%$ of the links that are issued in the network. The other actors from politics and the media only send very few links. When we look at these numbers in relation to the share of actor types in the network (Figure 2) we can see that NGOs, citizens and 'other' actors sent links to an over proportional extent, while the remaining actors did not. At the same time, we see that NGOs also receive links disproportionally. Here, the numbers are not that immoderate as in the case of link-sending; most of the other groups receive more or less a share of links that approaches their group share in the network, with political actors receiving slightly more and media, economic actors and citizens receiving less links compared to their actor share in the network. These data again corroborate that challengers are the dominating actors in the network.

Table 4: Interlinking patterns between different groups, share of all links.

\begin{tabular}{|l|c|c|c|c|c|r|r|}
\cline { 2 - 8 } \multicolumn{1}{c|}{} & \multicolumn{7}{c|}{ Link-receivers } \\
\hline Link-senders & Polit. Actors & SocEcoPresG & NGOs/CivSoc & Media & Citizens & Other & Total \% (n) \\
\hline Polit. Actors & $\mathbf{2 . 5 \%}$ & $\mathbf{0 . 2 \%}$ & $\mathbf{1 . 4 \%}$ & - & - & - & $\mathbf{4 . 1 \%}(\mathbf{1 8})$ \\
\hline SocEcoPresG & - & $\mathbf{0 . 7 \%}$ & $\mathbf{2 . 1 \%}$ & $\mathbf{0 . 2 \%}$ & - & - & $\mathbf{3 \%}(\mathbf{1 3})$ \\
\hline NGOs/CivSoc & $\mathbf{7 . 4 \%}$ & $\mathbf{4 . 8 \%}$ & $\mathbf{3 9 . 1 \%}$ & $\mathbf{2 2 . 3 \%}$ & $\mathbf{0 . 7} \%$ & $\mathbf{2 . 1 \%}$ & $\mathbf{7 6 . 3 \%}(\mathbf{3 3 2})$ \\
\hline
\end{tabular}




\begin{tabular}{|l|c|c|c|c|c|c|r|} 
Media & $0.5 \%$ & $0.7 \%$ & $4.1 \%$ & $0.5 \%$ & - & $0.2 \%$ & $6 \%(26)$ \\
\hline Citizens & $1.1 \%$ & - & $3.9 \%$ & $3.2 \%$ & $0.5 \%$ & $0.5 \%$ & $9.2 \%(40)$ \\
\hline Other & $0.7 \%$ & - & - & $0.5 \%$ & - & $0.2 \%$ & $1.4 \%(6)$ \\
\hline Total \% (n) & $12.2 \%(53)$ & $\mathbf{6 . 4 \%}(28)$ & $\mathbf{5 0 . 6 \% ( 2 2 0 )}$ & $\mathbf{2 6 . 7 \% ( 1 1 6 )}$ & $\mathbf{1 . 1 \% ( 5 )}$ & $\mathbf{3 \%}(13)$ & $\mathbf{1 0 0 \% ( 4 3 5 )}$ \\
\hline
\end{tabular}

From the single cells of table 4, we get an impression of the importance of ties between different groups of actors in the network. $39.1 \%$ of all links in the network are sent from NGOs to NGOs. Also links from NGOs to media $(22.3 \%)$ and to political actors $(7.4 \%)$ reach an important share. On the other hand, these two actor groups do not link back to the same extent to civil society actors: links from political actors to NGOs make up for only $1.4 \%$ and links from media to NGOs for $4.1 \%$ of all links. Thus, we see that challenger actors link more actively in the food safety network than other actor groups and that they indeed seek to be connected to actors from the media and politics. However the political actors and the media do not answer these links in the same way.

Another interesting finding can be derived from the share of links separated by the different groups in the network (Table 5). The percentages in the table may be interpreted only in a restricted manner due to the small total numbers in most of the rows. However, as these numbers represent the real findings in our network we shortly want to discuss them.

Table 5: Interlinking patterns between different groups, share of links by group.

\begin{tabular}{|c|c|c|c|c|c|c|c|}
\hline \multirow[b]{2}{*}{ Link-senders } & \multicolumn{7}{|c|}{ Link-receivers } \\
\hline & Polit. Actors & SocEcoPresG & NGOs/CivSoc & Media & Citizens & Other & Sum (n) \\
\hline Polit. Actors & $61.1 \%$ & $5.6 \%$ & $33.3 \%$ & - & - & - & $100 \%(18)$ \\
\hline SocEcoPresG & - & $23.1 \%$ & $69.2 \%$ & $7.7 \%$ & - & - & $100 \%(13)$ \\
\hline NGOs/CivSoc & $9.6 \%$ & $6.3 \%$ & $51.2 \%$ & $29.2 \%$ & $0.9 \%$ & $2.7 \%$ & $100 \%(332)$ \\
\hline Media & $7.7 \%$ & $11.5 \%$ & $69.2 \%$ & $7.7 \%$ & - & $3.8 \%$ & $100 \%(26)$ \\
\hline Citizens & $12.5 \%$ & - & $42.5 \%$ & $35 \%$ & $5 \%$ & $5 \%$ & $100 \%(40)$ \\
\hline Other & $50 \%$ & - & - & $33.3 \%$ & - & $16.7 \%$ & $100 \%(6)$ \\
\hline
\end{tabular}


The distribution of interlinking patterns as demonstrated in the first row shows that political actors tend to link to themselves on a high level. However, also a third of all of their links point to NGOs' websites. The links NGOs are sending (row 3) reflect somehow the findings from table 4, as more than half of their links are directed towards actors from their own group. However, there is considerable linking both to media (29.2\%) and political actors $(9.6 \%)$. In $6.3 \%$ of all cases, NGOs also link to economic actors; these however devote a majority of their 13 links to NGOs. This pattern can as well be observed for the media actors: almost $70 \%$ of their links are directed towards actors from civil society. Finally, citizens and single actors, in the way they link, resemble the other challenger actors from civil society. However, these actors rather link to other groups and only send a very low percentage of their links to their own group. For these actors, it seems to be attractive to be associated to "bigger" and more important actors and thus to profit from their importance.

Unfortunately, the analysis of the network could only take into account its structural attributes and cannot shed light on possible coalitions amongst actors connected through specific contents or frames on their websites. Thus, we may interpret some findings that we made in the case of our network in this way: when looking at the distribution of different organizations and organization types throughout the network, we found first indications for the existence of thematic clusters within the network. Those clusters may be built in connection to the main thematic focus of the organizations that build these clusters; they may roughly be labelled as "slow food", "food watch" and "agricultural" sub-networks as their central actors put an emphasis on these aspects of the food safety issue. 


\section{Discussion and outlook}

Summarizing our findings we see that the issue network of food safety challengers in Germany is mainly constituted by civil society actors. They are the most important group in the network both in terms of their share of all actors and also in terms of sending and receiving links. These finding reflects to some degree the approach of our study which starts with the identification of the network from challengers' websites and sets some other parameters such as degree of separation which affect the shape of the networks; therefore, the interpretation of the results has certain limitations, since challenger actors as our seed URLs are initially favoured in the network.

Even though the network speaks for a strong containment of the challenger network within the own movement sector, the media and political actors are also of central importance in the communication of those groups. While there is a high presence of media actors, their position is mostly rather at the periphery of the network. On the other hand, there are few political actors, but their position is very central, so they are to be seen as powerful actors in the network. Both groups seem to be attractive addressees of the challenger actors, but a considerable amount of their links is also directed towards the websites of NGOs and civil society actors.

The constellation of actors in the network reflects the diversification of actors in the food safety policy field. Civil society actors, economic actors as well as actors from the media and politics are contained in the online network and mutually link to each other, notwithstanding the varying degree of these linking patterns. Our analysis clearly demonstrates that challenger actors in Germany form a dense coalition in terms of hyperlink connections which leads us to the conclusion that there is a certain potential for both the mobilization on the issue and its

politicization. What is more, challenger actors seem especially to be keen on connecting to websites of media actors and to a lower degree to websites of powerful political actors as well. 
We may interpret this circumstance in the way that challenger actors try to include these important actors into their advocacy coalition in order to give their claims and goals a higher importance on the political agenda. Since media organizations are important actors in the network and also link to challenger actors to a considerable degree, we may consider that there is indeed the opportunity for challenger actors to make the food safety issue salient on the public agenda.

We further maintain that there is a potential for challenger actors to mobilize on the issue of food safety and to bring the issue to the political agenda as well, provided that the ties that could be observed in the online world are also reflected in the "real world" and "real" advocacy coalitions. However, the chance for challengers to make the issue salient on the media agenda seems to be quite good due to the presence of media actors in the network and their linking patterns, particularly when we keep in mind Chadwick's (2011) observation that old and new media are more and more interconnected. In a next step of research, these general assumptions should be analysed as to the "real" mobilization and politicization patterns.

Our findings based on our hyperlink network analysis serve as a proxy for alliances and actor constellations in the "real world". Further research is needed concerning the meaning of hyperlinks and the context in which they are set. In this regard, it might be useful to differentiate between links issued by challenger actors that target media articles on websites of media actors ('media linking') from those which are aimed at addressing or criticizing another actor ('critical linking') or those which serve to connect to other challenger actors ('movement linking') (Niesyto 2010: 283). Researching more on the background of links could then also lead to a broader understanding of patterns that could be found in the issue network such as the clustering of websites around some specific nodes. 
In a similar vein, one could have a look on the textual context in which hyperlinks are used and distinguish between links with positive or negative connotations (Bulkow et al. 2010). This would also be a first step towards analysing the content of web pages in order to assess which concrete claims are put forth and to be able to make a statement about possible frame coalitions that could exist between different actors. The assessment of thematic sub-networks and their role should be in the centre of future research; other important fields of research lie in the observation of the possible internationalization of the network or the change of networks over time; here, important questions may arise as to the possible impact of food scandals or campaigns on the configuration of the network.

\footnotetext{
${ }^{1}$ This publication was created in the context of the Research Unit "Political Communication in the Online World" (1381), subproject 7, which is funded by the Deutsche Forschungsgemeinschaft (DFG, German Research Foundation). The subproject is also funded by the Swiss National Science Foundation (SNSF). We want to thank the anonymous reviewers for their valuable comments on an earlier version of this text.

${ }^{2}$ Today, the name of the ministry is Federal Ministry of Food, Agriculture and Consumer Protection (BMELV).

${ }^{3}$ Important rearrangements in the policy field also took place on the European level, notably with the foundation of the European Food Safety Agency (EFSA) in 2002. However, the European level shall not be considered within the framework of this article.

${ }^{4}$ The full list of search terms was Lebensmittelsicherheit (food safety), Sicher + Lebensmittel (safe + food), Lebensmittelskandal (food scandal), Genfood (GM foods), Lebensmittel + Verbraucherschutz (food + consumer protection), Lebensmittel + Konsumenten (food + consumers), Lebensmittel + Risiko (food + risk), Lebensmittelsicherheit + Kampagne (food safety + campaign), Lebensmittel + Kennzeichnung (food + labelling), Lebensmittelsicherheit + Kontrolle (food safety + control).

${ }^{5}$ We received written information from one head of division at the BMELV and from one university environmental policy expert. Further we conducted an in-depth personal interview with an author who published several books on the issue of food policy.

${ }^{6}$ Within the overall research project, which compares networks across several countries and issues, this number of seeds was determined in order to keep networks comparable.

${ }^{7}$ Further information on this tool can be found on http://www.govcom.org/.

${ }^{8}$ We decided to stick to a degree of separation of 1 since a higher level would include also the outlinks from the websites that were included in the first step, thereby letting the network grow exponentially; this would make the handling (and coding) of data much more complex.

${ }^{9}$ Further information on this tool can be found on http://www.newprosoft.com/web-spider.htm.
} 
${ }^{10}$ The coding of domains was done by two trained coders; 259 domains were coded within a larger project context (see footnote 1). The variable "type of actor" reached an inter-coder reliability of .78 (Krippendorff"s $\alpha$ ).

${ }^{11}$ These categories do not exactly accord with the concept of challengers; in order to achieve this category, civil society actors and the group of citizens / private persons have to be taken together. 


\section{References}

Ackland, R. and O'Neil, M. (2011), 'Online collective identity: The case of the environmental movement', Social Networks, 33: 3, pp. 177-190.

aid infodienst (2012), 'About us', http://www.aid.de/profil/ueber_uns.php. Accessed 02 February 2013.

Anderson, W. A. (2000), 'The future relationship between the media, the food industry and the consumer', British Medical Bulletin, 56: 1, pp. 254-268.

Barlösius, E. (2011), Soziologie des Essens : Eine sozial- und kulturwissenschaftliche Einführung in die Ernährungsforschung (2 ed.). Weinheim: Juventa.

Baumgartner, F. and Jones, B. (1991), 'Agenda Dynamics and Policy Subsystems', The Journal of Politics, 53: 4, pp. 1044-1074.

Blue, G. (2010), 'Food, publics, science', Public Understanding of Science, 19: 2, pp. 147-154.

Bucher, H.-J., Erlhofer, S., Kallass, K. and Liebert, W.-A. (2008), 'Netzwerkkommunikation und Internet-Diskurse: Grundlagen eines netzorientierten Kommunikationsbegriffs' in A. Zerfaß, M. Welker and J. Schmidt (eds), Kommunikation, Partizipation und Wirkungen im Social Web. Köln: Halem, pp. 41-61.

Bulkow, C., Urban, J. and Schweiger, W. (2010), 'Meinungsführerschaft online messbar machen - ein hyperlink-inhaltsanalytischer Ansatz' in N. Jackob, T. Zerback, O. Jandura and M. Maurer (eds), Das Internet als Forschungsinstrument und -gegenstand in der Kommunikationswissenschaft. Köln: Halem, pp. 109-131.

Burris, V., Smith, E. and Strahm, A. (2000), 'White Supremacist Networks on the Internet', Sociological Focus, 33: 2, pp. 215-235.

Castells, M. (2010), The Rise of the Network Society (2 ed. Vol. 1). Malden, MA / Oxford: Blackwell.

Chadwick, A. (2006), Internet politics: states, citizens, and new communication technologies. New York, NY: Oxford University Press.

Chadwick, A. (2011), 'The Political Information Cycle in a Hybrid News System: The British Prime Minister and the "Bullygate" Affair', The International Journal of Press/Politics, 16: 1, pp. 3-29.

De Jonge, J., Van Trijp, H., Renes, R. J. and Frewer, L. J. (2010), 'Consumer Confidence in the Safety of Food and Newspaper Coverage of Food Safety Issues: A Longitudinal Perspective', Risk Analysis, 30: 1, pp. 125-142.

Diani, M. (2000), 'Social Movement Networks Virtual and Real', Information, Communication and Society, 3: 3, pp. 386-401. 
Feindt, P. H. and Kleinschmit, D. (2011), 'The BSE Crisis in German Newspapers: Reframing Responsibility', Science as Culture, 20: 2, pp. 183-208.

foodwatch (2012), 'foodwatch fights for consumers' rights', http://foodwatch.de/english/index_ger.html. Accessed 21 January 2013.

Gerhards, J. and Schäfer, M. S. (2010), 'Is the internet a better public sphere? Comparing old and new media in the USA and Germany', New Media \& Society, 12: 1, pp. 143-160.

Gonzalez-Bailon, S. (2009), 'Opening the black box of link formation: social factors underlying the structure of the web', Social Networks, 31: 4, pp. 271-280.

Govcom.org (2012), 'Instructions of Use', http://www.govcom.org/ Issuecrawler_instructions.htm. Accessed 21 January 2013.

Greenpeace (2012), 'Greenpeace-Erfolge für gesünderes Essen', http://www.greenpeace.de/themen/landwirtschaft/alternativen/artikel/greenpeace_erfolge_fuer_g esuenderes_essen/. Accessed 02 February 2013.

Habermas, J. (2006), 'Political Communication in Media Society: Does Democracy Still Enjoy an Epistemic Dimension? The Impact of Normative Theory on Empirical Research', Communication Theory, 16: 4, pp. 411-426.

Janning, F. (2011), Die Spätgeburt eines Politikfeldes. Die Institutionalisierung der Verbraucherschutzpolitik in Deutschland und im internationalen Vergleich. Baden-Baden: Nomos.

Jenkins-Smith, H. C. and Sabatier, P. A. (1994), 'Evaluating the Advocacy Coalition Framework', Journal of Public Policy, 14: 2, pp. 175-203.

Kim, J. H. (2012), 'A Hyperlink and Semantic Network Analysis of the Triple Helix (UniversityGovernment-Industry): The Interorganizational Communication Structure of Nanotechnology', Journal of Computer-Mediated Communication, 17: 2, pp. 152-170.

Kleinschmit, D. (2010), 'Die Bedeutung der Öffentlichkeit durch Print- und Onlinemedien für eine demokratische Politik - Eine Ernährungspolitische Perspektive', in M. Kayser, J. Böhm and A. Spiller (eds), Die Ernährungswirtschaft in der Öffentlichkeit. Social Media als neue Herausforderung der PR. Göttingen: Cuvillier, pp. 27-39.

Koopmans, R. (2004), 'Protest in time and space: the evolution of waves of contention', in D. A. Snow, S. A. Soule and H. Kriesi (eds), The Blackwell Campanion to Social Movements. Oxford: Blackwell Publishing, pp. 19-46.

Koopmans, R. and Statham, P. (1999), 'Ethnic and Civic Conceptions of Nationhood and the Differential Success of the Extreme Right in Germany and Italy', in M. Giugni, D. McAdam and C. Tilly (eds), How Social Movements Matter. Minneapolis, MN: University of Minnesota Press, pp. 225-251. 
Koopmans, R. and Zimmermann, A. (2010), 'Transnational Political Communication on the Internet: Search Engine Results and Hyperlink Networks', in R. Koopmans and P. Statham (eds), The Making of a European Public Sphere: Media Discourse and Political Contention. Cambridge: Cambridge University Press, pp. 171-194.

Kriesi, H. (2004), 'Strategic political communication: mobilizing public opinion in , audience democracies", in F. Esser and B. Pfetsch (eds), Comparing political communication. Theories, cases, and challenges. Cambridge: Cambridge University Press. pp. 184-212.

Kriesi, H., Koopmans, R., Duyvendak, J., and Guigni, M. (1992), , New social movements and political opportunities in Western Europe', European Journal of Political Research, 22: 2, pp. 219-244.

Lang, T., Barling, D. and Caraher, M. (2009), Food Policy - Integrating health, environment and society. Oxford: Oxford University Press.

Lien, M. E. (2004), 'The Politics of Food: An Introduction', in M. E. Lien and B. Nerlich (eds), The Politics of Food. Oxford / New York, NY: Berg, pp. 1-17.

Maeseele, P. (2011), 'On news media and democratic debate: Framing agricultural biotechnology in Northern Belgium', International Communication Gazette, 73: 1-2, pp. 83-105.

Marres, N. (2005), 'No Issue, No Public. Democratic Deficits after the Displacement of Politics', Ph.D. thesis, Amsterdam: University of Amsterdam.

Meine Landwirtschaft (2012a), 'For a new agricultural policy: Farms not agroindustries', http://www.meine-landwirtschaft.de/fileadmin/files/meine-landwirtschaft/my_agriculture_ our_choice.pdf. Accessed 02 February 2013.

Meine Landwirtschaft (2012b), 'About us', http://www.meine-landwirtschaft.de/english.html. Accessed 02 February 2013.

Niesyto, J. (2010), 'Integrieren/Vernetzen: Kampagnen im Zeichen des Netzwerkparadigmas ein Paradoxon', in S. Baringhorst, V. Kneip, A. März and J. Niesyto (eds), Unternehmenskritische Kampagnen. Politischer Protest im Zeichen digitaler Kommunikation. Wiesbaden: VS, pp. 264-313.

Park, H. W. (2003), 'Hyperlink Network Analysis: A New Method for the Study of Social Structure on the Web', Connections, 25: 1, pp. 49-61.

Paul, K. T. (2007), 'Food for Thought: Change and Continuity in German Food Safety Policy', Critical Policy Analysis, 1: 1, pp. 18-41.

Paul, K. T. (2009), 'Food Safety: A Matter of Taste? Food Safety Policy in England, Germany, the Netherlands, and the Level of the European Union', Ph.D. thesis, Amsterdam: University of Amsterdam. 
Pilny, A. and Shumate, M. (2012), 'Hyperlinks as Extensions of Offline Collective Action', Information, Communication and Society, 15: 2, pp. 260-286.

Raupp, J. (2011), 'Organizational Communication in a Networked Public Sphere', SCM Studies in Communication/Media, 0: 1, pp. 71-93.

Rhoades, E. and Ellis, J. D. (2010), 'Food Tube: Coverage of Food Safety Issues Through Video', Journal of Food Safety, 30: 1, pp. 162-176.

Rogers, R. (2002), 'Operating issue networks on the web', Science as Culture, 11: 2, pp. 191213.

Rucht, D., Yang, M. and Zimmermann, A. (2008), Politische Diskurse im Internet und in Zeitungen: Das Beispiel Genfood. Wiesbaden: VS.

Sabatier, P. (1988), 'An advocacy coalition framework of policy change and the role of policyoriented learning therein', Policy Sciences, 21: 2-3, pp. 129-168.

Sabatier, P. and Weible, C. (2007), 'The Advocacy Coalition Framework: Innovations and Clarifications', in P. Sabatier (ed), Theories of the Policy Process. Boulder, CO: Westview Press, pp. 189-220.

Slow Food (2002), 'Slow Food: Geschmack hat eine Lobby. Programmatische Erklärung von Slow Food Deutschland e.V.', http://www.slowmedia.de/manifest.pdf. Accessed 02 February 2013.

Tilly, C. (1987), From mobilization to revolution. Reading: Addison-Wesley.

Verbraucherzentrale Bundesverband (VZBV) (2012), ,About us', http://en.vzbv.de/About_us.htm. Accessed 21 January 2013.

Wassermann, S. and Faust, K. (1992), 'Centrality and Prestige: A Review and Synthesis', Journal of Quantitative Anthropology, 4: 1, pp. 23-78.

Webhits (2012), 'Nutzung von Suchmaschinen', http://www.webhits.de/deutsch/ index.shtml?/deutsch/webstats.html. Accessed 15 January 2013.

Whatley, K. W., Doerfert, D. L., Kistler, M. and Thompson, L. (2005), 'An examination of the food safety information sources and channels utilized and trusted by residents of Lubbock, Texas', Journal of Agricultural Education, 46: 3, pp. 70-81.

Wolfsfeld, G. (2011), Making Sense of Media and Politics: Five Principles in Political Communication. New York, NY / Abingdon: Routledge. 


\section{Contributor Details}

Peter Miltner is a research associate and $\mathrm{PhD}$ candidate at Freie Universität Berlin, Institute for Media and Communication Studies. He graduated in communication sciences at the University of Hohenheim in Stuttgart in 2009 and holds a Master's degree in European Interdisciplinary Studies from the College of Europe in Warsaw (2010). His areas of interest and research are political (online) communication and network analysis.

Contact: Freie Universität Berlin, Department of Political and Social Sciences, Institute for Media and Communication Studies, Division of Communication Theory and Media Effects, Garystr. 55, 14195 Berlin, Germany. E-Mail: peter.miltner@fu-berlin.de

Daniel Maier is a research associate at Freie Universität Berlin, Institute for Media and Communication Studies. He graduated in political science at the University of Passau (BA, 2006) and in communication science at Freie Universität Berlin (MA, 2012). His research interests include methods of network analysis and media policy.

Contact: Freie Universität Berlin, Department of Political and Social Sciences, Institute for Media and Communication Studies, Division of Communication Theory and Media Effects, Garystr. 55, 14195 Berlin, Germany. E-Mail: maier@zedat.fu-berlin.de

Barbara Pfetsch is a Full Professor of Communication Theory and Media Effects Research at Freie Universität Berlin. Her research focuses on comparative analyses of political communication and of media and public debate, processes of media agenda building and political communication on the Internet. She published several books, including "Political Communication Cultures in Western Europe" (2013), "Comparing Political Communication" (2004) and numerous articles and book chapters. Barbara Pfetsch held fellowships and visiting scholarships at the at the Center for Advanced Studies of the Behavioral Sciences at Stanford University (2012-2013), the Minda de Gunzberg Center for European Studies at Harvard University (20062007), the Shorenstein Center for the Press, Politics and Public Policy at Harvard's J.F. Kennedy School of Government (1997), and the Center for German and European Studies at Georgetown University, Washington, D.C. (1991-1992).

Contact: Freie Universität Berlin, Department of Political and Social Sciences, Institute for Media and Communication Studies, Division of Communication Theory and Media Effects, Garystr. 55, 14195 Berlin, Germany. E-Mail: pfetsch@zedat.fu-berlin.de

Annie Waldherr is a postdoctoral researcher at Freie Universität Berlin, Institute for Media and Communication Studies. In 2012, she received her PhD from Freie Universität Berlin for her dissertation on the dynamics of media attention. She graduated in communication science at the University of Hohenheim in Stuttgart in 2005 and stayed here working as a research associate at the Institute for Social Sciences until 2010. Her research interests include mediated public spheres, political online communication, science and technology discourses as well as social simulation.

Contact: Freie Universität Berlin, Department of Political and Social Sciences, Institute for Media and Communication Studies, Division of Communication Theory and Media Effects, Garystr. 55, 14195 Berlin, Germany. E-Mail: annie.waldherr@fu-berlin.de 